\title{
Rheumatism in Foundry Workers
}

\section{J. S. LAWRENCE, M. K. MOLYNEUX, and IANTHE DINGWALL-FORDYCE \\ From the Arthritis and Rheumatism Council Field Unit and the Nuffield Department of Occupational Health, University of Manchester}

In order to investigate loss of work from rheumatic diseases in the metal trades, employees in ro foundries were questioned.

Of 325 foundry workers aged 35 to 74 years, who had worked for at least ro years on the foundry floor, 299 were examined clinically and radiologically for evidence of rheumatic disease. Radiographs of the hands, knees, and dorsal and lumbar spine were taken as a routine, and the pelvis was included in those aged 45 and over. A comparison was made with a control series of radiographs, from men, matched for age, in a random population sample examined earlier in the town of Leigh.

Rheumatic complaints in general were less frequent in the foundry workers than in the random sample, and the foundry workers less often gave a history of prolonged incapacity (three months or more) due to this cause.

Radiological evidence of disc degeneration in the lumbar spine, however, was more frequent in the foundry workers than in the controls and was of greater severity. Further, the foundry workers more commonly had symptoms and signs of lumbar disc prolapse. On the other hand, the controls had more osteo-arthrosis of the hips and knees and lost more work from pain at these sites. This was associated with a difference of body habitus, obesity being less frequent in the foundry workers.

Foundry workers directly exposed to hot conditions did not have less back or leg pain than those not so exposed despite a greater prevalence of disc degeneration.

Measurements of air temperature, humidity, and radiant heat were made in a foundry while pouring was in progress. The air temperature rose from $18^{\circ} \mathrm{C}$. to $26^{\circ} \mathrm{C}$. and the humidity ranged from $70 \%$ to $54 \%$. The mean intensity of radiation incident on the clothed surface of a foundry worker was $0.12 \mathrm{watt} / \mathrm{cm}^{2}$. This was compared with conditions during therapeutic exposure to radiant heat. The radiant heat under conditions of 'heat therapy' varied between 0.16 and 0.37 watt $/ \mathrm{cm}^{2}{ }^{2}$. The possible influence of radiant heat on the prevalence of rheumatic complaints is discussed.

Statistics produced by the Ministry of Pensions and National Insurance in the United Kingdom indicate that, if unskilled workers are excluded, the greatest number of claims for incapacity due to arthritis and rheumatism (excluding rheumatic fever) are made by persons engaged in metal, engineering, and allied trades. In June 1955, for example, claims were received from 4,080 workers in these trades compared with 5,760 unskilled workers and 3,400 miners. The number of workers at risk is not accurately known but there can be little doubt that this reflects in part the frequency of such occupations in the community. In the absence of reliable information on the size and age distribution of this occupational group it was decided to carry out a detailed survey. As foundry workers form a well defined sub-group and lose work more

Received for publication April I0, 1965. frequently than any other metal workers, this survey was limited to foundry workers. Statistics produced by the Amalgamated Union of Foundry Workers show that rheumatism is an important cause of incapacity in their members, coming second only to respiratory disease and influenza.

Little has appeared in the medical literature on this subject but Vernon (I92I) found that puddlers of wrought iron lost an excessive amount of work from rheumatism and he attributed this to periods of heavy work under high temperature conditions followed by sitting about in draughts. Steel melters, who are also engaged in heavy intermittent work, lost more than the average amount of work from rheumatism.

\section{Method of Survey}

Foundries, whether attached to large engineering 
shops or acting as independent units, are usually small and employ on an average some 30 men. It was therefore felt that a survey of a single large foundry would not give a representative sample. It was decided to include one foundry with more than 200 employees and to distribute the rest of the survey over a number of smaller foundries* employing 20 to 100 men.

The survey was limited to men aged 35 and over, who had worked for at least Io years on the foundry floor and were so working at the time of the survey or were temporarily away from their work because of sickness or accident. No information was available on foundry men who had left the industry because of illness but these were considered by the management to be few. Trades included were moulders, coremakers, dressers and arc welders, pattern makers, and general labourers.

After a history had been taken of past illnesses and present symptoms, a clinical examination of the musculo-skeletal system was carried out on all men having the above qualifications. Radiographs were taken of the hands, knees, and dorsal and lumbar spine as a routine and of the pelvis in those aged 45 and over. Only a lateral view was taken of the spine and an anterior-posterior view of the other parts. A comparison was made with a series of radiographs from the Leigh random population sample (Lawrence and Bennett, 1960) matched by age with the foundry workers. As there were insufficient men aged 35 to 44 in the Leigh sample, 26 men in this age group were obtained from an area sample in Wensleydale (Bremner, 196r) to complete the

«The following foundries took part in the survey: J. Needham \& Sons, Stockport, Cheshire; J. R. Clayton, Stockport, Cheshire; Storey Foundry Co., Reddish, Cheshire; E. Pass \& Co., Denton, Lancashire; R. Broadbent \& Sons, Stalybridge, Cheshire; Ferranti Ltd., Hollinwood, Lancashire; J. Hodgkinson (Salford) Ltd., Salford, Lancashire; W. H. Bailey \& Co., Patricroft, Lancashire; Warrington Light Castings Co., Warrington, Lancashire; Wyman's Foundry, Warrington, Lancashire. controls. The radiographs of the foundry workers and controls were mixed randomly and read 'blind'. The changes found were graded in accordance with the Atlas of Standard Radiographs of Arthritis (I963).

The sample of foundry workers totalled 325 , of whom 299 were examined, a completion rate of $92 \%$. The $8 \%$ who were not examined were mainly in the 45-54 age group (Table I).

TABLE I

Completeness of SuRvey

\begin{tabular}{lrcrc} 
Age & $\begin{array}{l}\text { Total in } \\
\text { Sample }\end{array}$ & $\begin{array}{l}\text { Not Avail- } \\
\text { able or } \\
\text { Refused } \\
\text { Examination }\end{array}$ & Examined & $\begin{array}{l}\text { Completion } \\
\text { Rate (\%) }\end{array}$ \\
\hline $35-44$ & 126 & 6 & 120 & 95 \\
$45-54$ & 119 & 13 & 106 & 89 \\
$55-64$ & 69 & 2 & 67 & 97 \\
$65+$ & 6 & 0 & 6 & 100 \\
Not stated & 5 & 5 & - & - \\
Total & 325 & 26 & 299 & 92
\end{tabular}

\section{Results}

Rheumatic Symptoms Of the 299 foundry workers who were examined, $188(63 \%)$ gave a history of rheumatic complaints (Table II). The expected number, as determined by correction of the Leigh random males to the age distribution of the foundry workers, is $219\left(\chi^{2}=4.3, P<0.05\right)$. Of the 188 foundry workers with symptoms, I03 had lost work from rheumatism and 26 had lost three months or more compared with expected rates of I04 and 43. The difference between the number of foundry workers and controls who lost three months or more is significant $\left(\chi^{2}=6.3, P<0.02\right)$. The number of foundry workers with symptoms at the time of the survey was 80 , and two were actually off work from rheumatism, compared with an expected I07 with complaints $\left(\chi^{2}=6.5, \mathrm{P}<0.01\right)$ and five off work. None had been off for three months or

TABLE II

RHEUMATIC COMPLAINTS IN FOUNDRY WORKERS

\begin{tabular}{|c|c|c|c|c|c|c|c|}
\hline \multirow[t]{3}{*}{ Age } & \multirow[t]{3}{*}{ Total } & \multicolumn{3}{|l|}{ Since Birth } & \multicolumn{3}{|l|}{ Now } \\
\hline & & \multirow{2}{*}{$\begin{array}{l}\text { Total with } \\
\text { Complaints }\end{array}$} & \multicolumn{2}{|l|}{ Off Work } & \multirow{2}{*}{$\begin{array}{l}\text { Total with } \\
\text { Complaints }\end{array}$} & \multicolumn{2}{|l|}{ Off Work } \\
\hline & & & I Week + & 3 Months + & & I Week + & 3 Months + \\
\hline $35-44$ & 120 & 74 & 35 & 10 & 30 & I & - \\
\hline $45-54$ & 106 & 66 & 38 & 9 & 30 & $\mathbf{I}$ & - \\
\hline $55-64$ & 67 & 47 & 29 & 7 & 20 & - & 一 \\
\hline $65+$ & 6 & I & I & - & - & 一 & - \\
\hline Total & 299 & $188 \star$ & 103 & $26 *$ & $80 \dagger$ & 2 & 一 \\
\hline Expected & & 219 & 104 & 43 & 107 & 5 & 3 \\
\hline
\end{tabular}

$\star \mathbf{P}<0.05 . \quad+\mathbf{P}<0.01$. 
TABLE III

\begin{tabular}{|c|c|c|c|c|c|c|}
\hline & SITE & IN IN Fou & WORKERS & ONTROLS & & \\
\hline & Total & & Off Work & $e k+$ & Off Work & onths + \\
\hline & Foundry & Expected & Foundry & Expected & Foundry & Expected \\
\hline $\begin{array}{l}\text { Segmental } \\
\mathrm{CI}_{1} 4 \\
\mathrm{C}_{5}-\mathrm{D}_{2}\end{array}$ & $\begin{array}{l}12 \\
40 \dagger\end{array}$ & $\begin{array}{l}18 \\
60\end{array}$ & $\begin{array}{r}7 \\
26\end{array}$ & $\begin{array}{l}13 \\
27\end{array}$ & $\begin{array}{l}3 \\
4\end{array}$ & $\begin{array}{l}3 \cdot 7 \\
3 \cdot 3\end{array}$ \\
\hline $\begin{array}{l}D_{3}-11 \\
D_{12-L 2}\end{array}$ & $\begin{array}{l}46 \\
90\end{array}$ & $\begin{array}{l}40 \\
89\end{array}$ & $\begin{array}{l}29 \\
59\end{array}$ & $\begin{array}{l}20 \\
51\end{array}$ & $\begin{array}{r}6 \\
15\end{array}$ & $\begin{array}{r}4 \cdot 0 \\
18 \cdot 7\end{array}$ \\
\hline $\begin{array}{l}\mathrm{L}_{3}-4 \\
\mathrm{~L}_{5}-\mathrm{S}_{2}\end{array}$ & $\begin{array}{l}12 \ddagger \\
25\end{array}$ & $\begin{array}{l}34 \\
22\end{array}$ & $\begin{array}{c}7 \dagger \\
16\end{array}$ & $\begin{array}{l}23 \\
14\end{array}$ & $\begin{array}{l}\text { of } \\
5\end{array}$ & $\begin{array}{l}8 \cdot 6 \\
6 \cdot 7\end{array}$ \\
\hline $\begin{array}{l}\text { Local } \\
\text { Fingers } \\
\text { Thumbs }\end{array}$ & $\begin{array}{l}\text { I0 } \\
2^{\star}\end{array}$ & $\begin{array}{r}17 \\
8\end{array}$ & $\begin{array}{l}5 \\
2\end{array}$ & $\begin{array}{r}10 \\
6\end{array}$ & $\begin{array}{l}2 \\
0\end{array}$ & $\begin{array}{l}3 \cdot 7 \\
3 \cdot 0\end{array}$ \\
\hline $\begin{array}{l}\text { Wrists } \\
\text { Elbows }\end{array}$ & $\begin{array}{l}16 \\
25\end{array}$ & $\begin{array}{l}13 \\
18\end{array}$ & $\begin{array}{r}9 \\
14\end{array}$ & $\begin{array}{l}10 \\
13\end{array}$ & $\begin{array}{l}3 \\
4\end{array}$ & $\begin{array}{l}3 \cdot 7 \\
0\end{array}$ \\
\hline $\begin{array}{l}\text { Shoulders } \\
\text { Hips }\end{array}$ & $\begin{array}{l}30 \\
5\end{array}$ & $\begin{array}{l}43 \\
14\end{array}$ & $\stackrel{19}{I^{\star}}$ & $\begin{array}{r}18 \\
8\end{array}$ & $\begin{array}{l}2 \\
0\end{array}$ & $\begin{array}{l}0.1 \\
1 \cdot 4\end{array}$ \\
\hline $\begin{array}{l}\text { Knees } \\
\text { Ankles }\end{array}$ & $\begin{array}{r}31 \ddagger \\
5 \dagger\end{array}$ & $\begin{array}{l}57 \\
18\end{array}$ & $\begin{array}{c}15 \ddagger \\
5\end{array}$ & $\begin{array}{l}35 \\
10\end{array}$ & $\begin{array}{l}4^{\star} \\
3\end{array}$ & $\begin{array}{r}12 \cdot 9 \\
3 \cdot 0\end{array}$ \\
\hline $\begin{array}{l}\text { Tarsi } \\
\text { Toes }\end{array}$ & $\begin{array}{l}3 \ddagger \\
5\end{array}$ & $\begin{array}{r}20 \\
6\end{array}$ & $\begin{array}{l}2^{\star} \\
4\end{array}$ & $\begin{array}{l}8 \\
5\end{array}$ & $\begin{array}{l}\mathbf{I} \\
\mathbf{2}\end{array}$ & $\begin{array}{l}5 \cdot 0 \\
4 \cdot 3\end{array}$ \\
\hline $\begin{array}{l}\text { Multiple Undefined } \\
\star \mathrm{P}<0.05 . \\
+\mathrm{P}<0.01 . \\
\ddagger \mathrm{P}<0.001\end{array}$ & $4^{\star}$ & II & 3 & 8 & I & $4 \cdot 2$ \\
\hline
\end{tabular}

more with rheumatic troubles at the time of the survey though this would be expected in three. Complaints were mainly of pain in the low back and groins in the Dr2-L2 segmental distribution (Table III). In no sites, apart from the wrists and elbows and in the $D_{3-I I}$ and $L_{5}-S_{2}$ distribution (sciatic), was pain more frequent in the foundry workers, and here the differences were not significant. There was significantly less pain at a number of sites in the foundry workers, notably in the knees, ankles, and tarsi $(\mathbf{P}<0.001)$. Segmental pain in the legs and arms in the $\mathrm{L}_{3}-4$ and $\mathrm{C}_{5}-\mathrm{D}_{2}$ distribution was also significantly less frequent in the foundry workers. Loss of work due to pain in the hips, knees, and tarsi and in the L3-4 segmental distribution was less frequent in the foundry workers.

Radiological Findings In the lumbar spine the foundry workers had more disc degeneration of grades 2,3 , and 4 and less of grade $o$ than the controls (Table IV). Grade 3-4 disc degeneration was encountered in $18 \%$ of the foundry workers and in II \% of the controls and was more frequent at all ages in the foundry workers $\left(\chi^{2}=4.5, P \simeq 0.04\right)$.
The number of discs affected was similar in the foundry workers and controls, $25 \%$ and $27 \%$ respectively having involvement of four or more discs. The control group included 79 coal-miners who are known to exhibit severe disc degeneration (Kellgren and Lawrence, 1952). When these were removed the prevalence of grade 3-4 disc degeneration fell slightly, the mean equivalent rate, after correction for age distribution, being 10\% compared with $12 \%$ in the total control group and $18 \%$ in the foundry workers. The difference between the foundry workers and non-miners, taking age into account, is highly significant $(P<0.001)$.

Of the foundry workers, the moulders and general labourers showed the greatest frequency of disc degeneration, $20 \%$ and $22 \%$ respectively having grade 3-4 disc degeneration. Grade 4 disc degeneration, however, was found only in moulders. The high prevalence and severity of disc degeneration in moulders cannot be explained by age distribution since half of them were in the youngest age group, but the labourers had less than a third in this age group and would thus be expected to have a higher prevalence. There was no difference between those 
TABLE IV

Lumbar Disc Degeneration

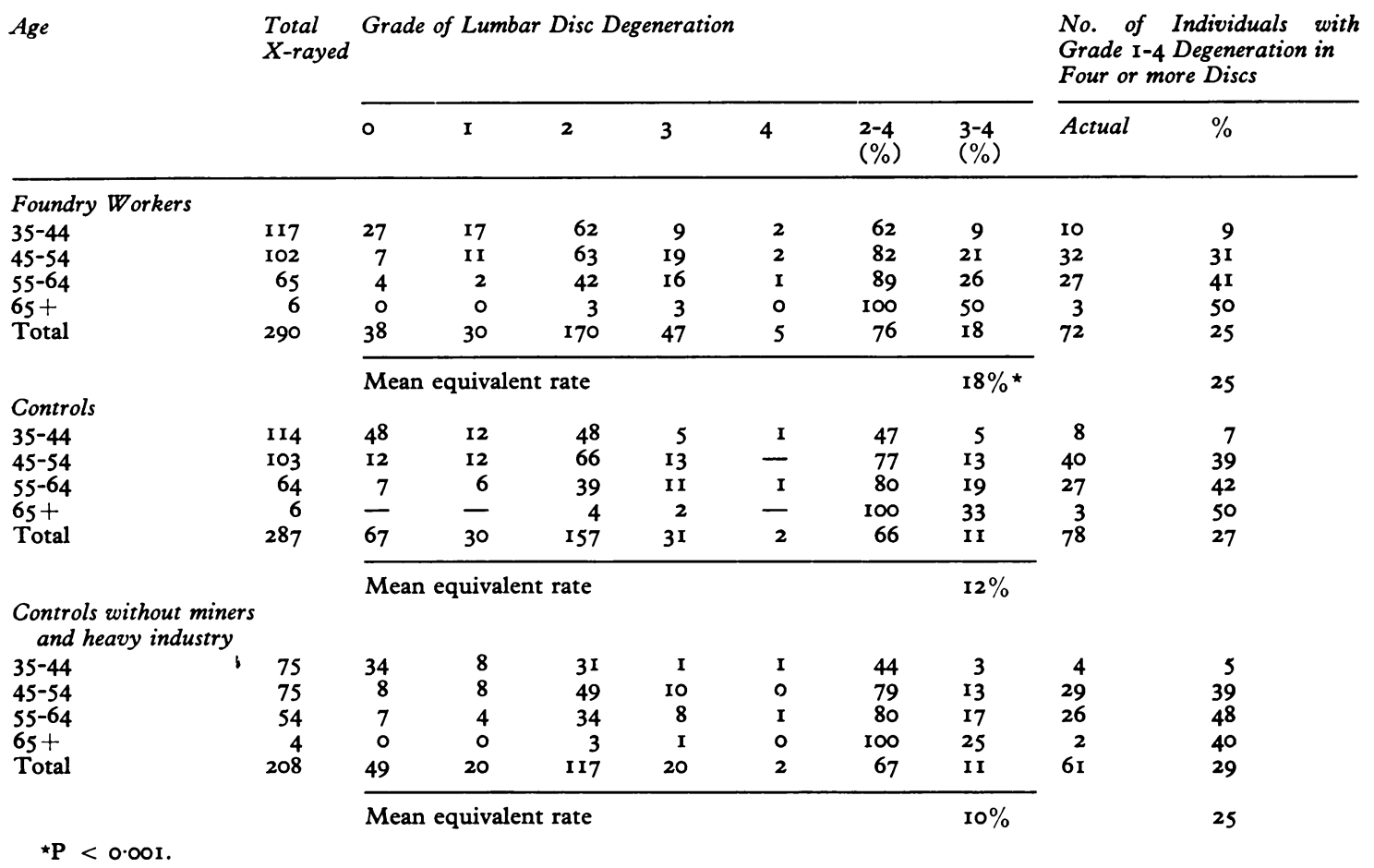

workers in the large foundry and those in the smaller had radiographs of this region (Table V). Control foundries as regards frequency and severity of radiographs of the dorsal spine were available in lumbar disc degeneration.

only II 4 , of whom $81 \%$ had grade $2-4$ disc degenera-

In the dorsal spine disc degeneration grade 2-4 tion. These were not selected in any way but reprewas found in $70 \%$ of the 289 foundry workers who sent the second half of the Leigh survey. After

TABLE V

DORSAL DisC DEgeneration

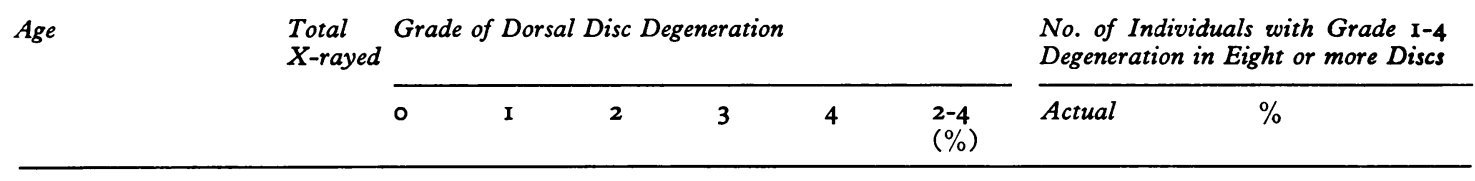

\begin{tabular}{|c|c|c|c|c|c|c|c|c|c|}
\hline \multicolumn{10}{|c|}{ Foundry Workers } \\
\hline $35-44$ & II 7 & 42 & 3 & 66 & 6 & $\circ$ & 61 & 0 & o \\
\hline $45-54$ & IOI & 21 & 5 & 59 & 16 & o & 74 & 2 & 2 \\
\hline $55-64$ & 65 & 8 & I & 29 & 26 & $\mathbf{I}$ & 86 & 3 & 5 \\
\hline $65+$ & 6 & 0 & o & 3 & 3 & 0 & 100 & I & 17 \\
\hline \multirow[t]{2}{*}{ Total } & 289 & 71 & 9 & 157 & 51 & I & 70 & 6 & 2 \\
\hline & & \multicolumn{5}{|c|}{ Equivalent average rate } & \multicolumn{2}{|c|}{$80 \%$} & 6 \\
\hline \multicolumn{10}{|c|}{ Controls } \\
\hline $35-44$ & 44 & I I & 3 & 25 & 5 & $\circ$ & 68 & $\mathbf{I}$ & 2 \\
\hline $45-54$ & 49 & 4 & $\mathbf{I}$ & 33 & I I & o & 90 & 4 & 8 \\
\hline $55-64$ & 15 & I & $\mathbf{I}$ & 9 & 4 & $\circ$ & 87 & I & 7 \\
\hline $65+$ & 6 & 0 & $\mathbf{I}$ & 2 & 2 & $\mathbf{r}$ & 83 & $\mathbf{I}$ & 17 \\
\hline \multirow[t]{2}{*}{ Total } & II4 & I6 & 6 & 69 & 22 & $\mathbf{I}$ & $8 \mathrm{I}$ & 7 & 6 \\
\hline & & \multicolumn{5}{|c|}{ Equivalent average rate } & \multicolumn{2}{|c|}{$82 \%$} & 8 \\
\hline
\end{tabular}


TABLE VIA

RADIOLOGICAL OSTEO-ARTHROSIS OF THE HANDS

Age
Foundry Workers

\begin{tabular}{lllllll}
\hline Total & \multicolumn{3}{l}{ Grade } \\
\cline { 2 - 6 } -rayed & 0 & I & 2 & 3 & 4 & $2-4$
\end{tabular}
Controls

Total Grade

$X$-rayed

$\begin{array}{llllll}0 & 1 & 2 & 3 & 4 & 2-4\end{array}$

\begin{tabular}{|c|c|c|c|c|c|c|c|c|c|c|c|c|c|}
\hline \multicolumn{14}{|c|}{ Distal Interphalangeal foints } \\
\hline $35-44$ & 120 & 106 & 9 & 4 & $\mathbf{I}$ & 0 & $119^{*}$ & 105 & 6 & 7 & $\mathbf{I}$ & 0 & \\
\hline $45-54$ & 106 & 76 & 8 & 19 & 3 & 0 & 106 & 61 & I I & 33 & $\mathbf{I}$ & $\mathbf{0}$ & \\
\hline $55-64$ & 67 & 26 & 17 & 19 & 5 & 0 & 67 & 27 & II & 24 & 5 & 0 & \\
\hline $65+$ & 6 & 2 & I & 3 & 0 & 0 & $65+$ & 0 & I & 3 & 2 & 0 & \\
\hline Total & 299 & 210 & 35 & 45 & 9 & 0 & $18 \%$ * 298 & 193 & 29 & 67 & 9 & 0 & $26 \%$ \\
\hline \multicolumn{14}{|c|}{ Proximal Interphalangeal foints } \\
\hline $35-44$ & 120 & II6 & 0 & 4 & 0 & 0 & $119^{*}$ & 116 & $\mathbf{I}$ & 2 & 0 & o & \\
\hline $45-54$ & 106 & 94 & 5 & 7 & 0 & 0 & 106 & 96 & 7 & 3 & o & 0 & \\
\hline $55-64$ & 67 & 50 & 5 & II & $\mathbf{I}$ & 0 & 67 & 51 & 7 & 8 & $\mathbf{I}$ & o & \\
\hline $65+$ & 6 & 4 & I & $\mathbf{I}$ & 0 & 0 & 6 & 3 & $\mathbf{I}$ & 2 & 0 & 0 & \\
\hline Total & 299 & 264 & II & 23 & I & 0 & $8 \%$ * 298 & 266 & 16 & 15 & $\mathbf{I}$ & 0 & $5 \%$ \\
\hline \multicolumn{14}{|c|}{ Metacarpophalangeal foints } \\
\hline $35-44$ & 120 & 112 & 3 & 5 & 0 & o & 119* & 105 & 9 & 5 & 0 & 0 & \\
\hline $45-54$ & 106 & 83 & 10 & II & 2 & 0 & 106 & 72 & 18 & 16 & o & 0 & \\
\hline $55-64$ & 67 & 45 & 5 & 13 & 4 & 0 & 67 & 40 & 9 & 16 & 2 & 0 & \\
\hline $65+$ & 6 & 3 & $\mathbf{I}$ & 0 & 2 & 0 & 6 & 3 & 2 & 0 & $\mathbf{I}$ & 0 & \\
\hline Total & 299 & 243 & I9 & 29 & 8 & 0 & $12 \%$ & 220 & 38 & 37 & 3 & 0 & $13 \%$ \\
\hline \multicolumn{14}{|c|}{ Carpometacarpal and Intracarpal foints } \\
\hline $35-44$ & 120 & 113 & 6 & I & 0 & 0 & II9* & 106 & 10 & 3 & 0 & 0 & \\
\hline $45-54$ & 106 & 88 & 7 & 10 & $\mathrm{I}$ & 0 & 106 & 78 & 13 & 14 & I & 0 & \\
\hline $55-64$ & 67 & 48 & 9 & 5 & 5 & 0 & 67 & 43 & II & II & I & I & \\
\hline $65+$ & 6 & I & 2 & 2 & I & 0 & 6 & 4 & 0 & I & I & 0 & \\
\hline Total & 299 & 250 & 24 & 18 & 7 & 0 & 298 & $23 \mathrm{I}$ & 34 & 29 & 3 & I & $11 \%$ \\
\hline
\end{tabular}

TABLE VIB

Radiological Osteo-ARTHROSIS OF THE SPINE AND LOWER LimBS

Age

Foundry Workers

Controls

\begin{tabular}{|c|c|c|c|c|c|c|c|c|c|c|c|c|c|}
\hline \multirow{2}{*}{$\begin{array}{l}\text { Total } \\
X \text {-rayed }\end{array}$} & \multicolumn{6}{|c|}{ Grade } & \multirow{2}{*}{$\begin{array}{l}\text { Total } \\
X \text {-rayed }\end{array}$} & \multicolumn{6}{|c|}{ Grade } \\
\hline & 0 & I & 2 & 3 & 4 & $2-4$ & & 0 & $\mathbf{I}$ & 2 & 3 & 4 & $2-4$ \\
\hline
\end{tabular}

Lumbar Spine

35-44

45-54

$55-64$

$65+$

Total

Hips

45-54

$55-64$

$65+$

Total

Sacro-iliac foint

45-54

55-64

$65+$

Total

Knees

35-44

45-54

55-64

$65+$

Total

$\star \mathbf{P}<0.01$.
II 7

102

65

290

100

64
6

170

98
64
6

178

II8

103

67
6

294

$\begin{array}{ll}85 & 23 \\ 64 & 25\end{array}$

6425

$\begin{array}{rr}3 & 2 \\ 191 & 65\end{array}$

$\begin{array}{rrrrr}82 & 11 & 6 & 1 & 0 \\ 43 & 13 & 7 & 1 & 0 \\ 4 & 0 & 2 & 0 & 0 \\ 129 & 24 & 15 & 2 & 0\end{array}$

$\begin{array}{rrrrr}93 & 3 & 2 & 0 & 0 \\ 52 & 8 & 4 & 0 & 0 \\ 4 & 1 & 1 & 0 & 0 \\ 157 & 14 & 7 & 0 & 0\end{array}$

$\begin{array}{rrrr}100 & 12 & 6 & 0 \\ 73 & 17 & 12 & 1 \\ 42 & 11 & 11 & 3 \\ 2 & 1 & 3 & 0 \\ 217 & 41 & 32 & 4\end{array}$

18

(II

$\begin{array}{lll}8 & 1 & 0 \\ 1 & 2 & 0 \\ 8 & 3 & 0\end{array}$


TABLE VII

Disc Prolapse In Foundry WORKers

\begin{tabular}{|c|c|c|c|c|c|c|c|c|c|c|c|c|c|}
\hline \multirow[t]{4}{*}{ Age } & \multirow[t]{4}{*}{ Total } & \multicolumn{12}{|c|}{ Grade of Disc Prolapse } \\
\hline & & \multicolumn{6}{|c|}{ Cervical } & \multicolumn{4}{|c|}{ Lumbar } & & \\
\hline & & \multicolumn{4}{|c|}{ Actual } & \multicolumn{2}{|c|}{ Expected } & \multicolumn{4}{|c|}{ Actual } & \multicolumn{2}{|c|}{ Expected } \\
\hline & & 0 & $\mathbf{I}$ & 2 & 3 & $I-3$ & $2-3$ & 0 & $\mathbf{I}$ & 2 & 3 & $1-3$ & $2-3$ \\
\hline $35-44$ & 120 & & $\mathbf{I}$ & $\mathbf{I}$ & 0 & & & & 6 & 3 & 2 & & \\
\hline $45-54$ & 106 & & & & 0 & & & & 7 & 5 & $\mathbf{I}$ & & \\
\hline $55-64$ & 67 & & & $\mathbf{I}$ & 0 & & & & 3 & 5 & 2 & & \\
\hline $65+$ & 6 & & & & 0 & & & & & & 0 & & \\
\hline Total & 299 & & $\mathbf{I}$ & 2 & o & $3.11 \%$ & $1 \cdot 41 \%$ & & 16 & 13 & 5 & $9 \cdot 4$ & $5.21 \%$ * \\
\hline
\end{tabular}

correction for age distribution the proportions were $80 \%$ in the foundry workers and $82 \%$ in the controls. Changes were present in eight or more discs in $6 \%$ of the foundry workers and $8 \%$ of the controls after age-correction. It may be concluded that there is no increase of degenerative disc change in the dorsal spine in foundry workers.

Osteo-Arthrosis The foundry workers had significantly less osteo-arthrosis than the controls in the apophyseal joints of the lumbar spine and in the distal interphalangeal joints of the fingers but particularly in the knees and hips $(P<0.01)$. In none of the joints was there significantly more osteoarthrosis in the foundry workers (Table VI). The lowest prevalence of osteo-arthrosis of the hips was found in the miscellaneous group of foundry workers, of whom only $3 \%$ had definite radiological changes, and of osteo-arthrosis of the knees in the dressers, only $3 \%$ of whom were affected.

Rheumatoid Arthritis Only two foundry workers were diagnosed as having rheumatoid arthritis on clinical examination, and in both cases it was of minimal severity. The expected number in a sample of this age distribution, as calculated from the random population samples in the North of England, would be nine (Lawrence, 196I). Because of the small numbers there was no significant difference between foundry workers and the general population. Radiological evidence of erosive arthritis was found in $26(9 \%)$ of the foundry workers and in $21(7 \%)$ of the controls. In all but one in each group it was of minimal severity. Persons with severe rheumatoid arthritis are unable to undertake heavy manual work, which may well account for the lower prevalence of this disease in the foundry workers.

Other Diseases A diagnosis of disc prolapse was made in 36 of the foundry workers. Of those with disc prolapse, 33 had lumbar prolapse alone, two cervical alone and one both. Of those with lumbar disc prolapse, I6 had it at grade I severity, and 18 at grade 2-3 (Table VII). The numbers expected to have lumbar disc prolapse judged from the population sample in Leigh would be five grade I and five grade 2-3. There was thus more than three times the expected amount of lumbar disc prolapse in the foundry workers, a very significant increase. The increased prevalence of lumbar disc prolapse was not limited to any one occupation in the foundry, those affected being evenly distributed among the occupational groups. Cervical disc prolapse was found to have approximately the same prevalence as in the random sample.

Spondylitis was diagnosed on clinical examination and confirmed by radiography in two foundry workers. This prevalence of $0.7 \%$ is not significantly greater than the prevalence of $0.4 \%$ noted in men from random population surveys in the North of England (Lawrence, 1963). Radiological evidence of sacro-iliitis was noted in $4 \%$ of the foundry workers and in $4 \%$ of the controls. Except in the two foundry workers with spondylitis, it was of minimal severity. Other connective tissue disorders encountered were capsulitis or synovitis in eight foundry workers, Dupuytren's contracture in two, bursitis in three, and gout in three.

\section{Relationship of Symptoms and Loss of Work to Radiological Changes}

Comparison of Foundry Workers and Controls A relationship between the radiological changes of osteo-arthrosis in the hips, knees, and joints of the hands and pain in the region of these joints has been demonstrated in random population samples (Bier, Bremner, and Lawrence, 1965). Disc degeneration in the lumbar spine has similarly been shown to be related to back-sciatic pain (Lawrence, de Graff, and Laine, 1963). No relationship was found in those 
studies between dorsal disc degeneration and dorsal pain or between osteo-arthrosis of the dorsal or lumbar apophyseal joints and symptoms. In Table VIII the frequency of pain and incapacity at various sites in the foundry workers is compared with the expected frequency determined from the Leigh random sample after adjustment for age and frequency of radiological change. Despite a higher prevalence of lumbar disc degeneration in the foundry workers there were fewer symptoms than

\section{TABLE VIII}

Symptoms and Incapacity from Pain at CeRtain Sites in Relation to AMOUNT OF DISC DEgENERATION OR OSTEO-ARTHROSIS

Site of X-ray Changes

Site of

Number with Pain Number off Work

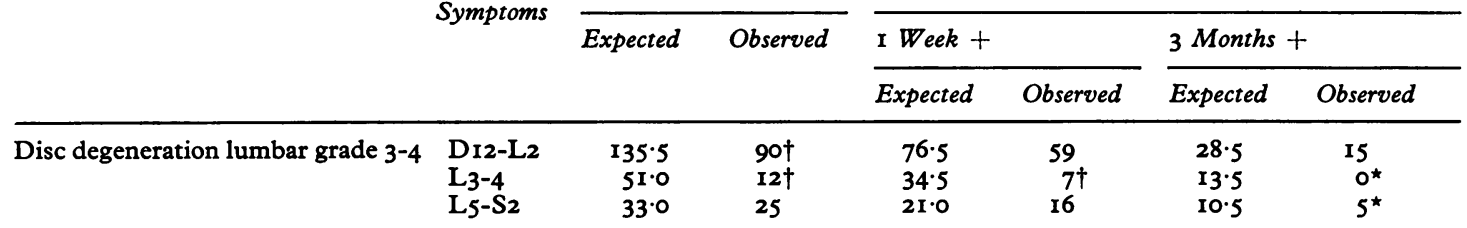

Osteo-arthrosis grade 2-4

Hips

Knees

First carpometacarpal joint

Wrists

Distal interphalangeal joint

Proximal interphalangeal joint

Metacarpophalangeal joint

$\begin{array}{lr}\text { Hips } & 7 \cdot 0 \\ \text { Knees } & 31 \cdot 1 \\ \text { Thumbs } & 5 \cdot 8 \\ \text { Wrists } & 11 \cdot 0 \\ \text { Fingers } & 11 \cdot 8 \\ \text { Fingers } & 40 \cdot 0 \\ \text { Fingers } & 19 \cdot 4\end{array}$

TABLE IX

Symptoms and Absence Due to Back and Leg Pain in Workers Exposed to Radiant Heat IN THE FoundRY

\begin{tabular}{|c|c|c|c|c|c|c|c|c|}
\hline \multirow{3}{*}{$\begin{array}{l}\text { Conditions } \\
\text { of Work }\end{array}$} & \multirow{3}{*}{$\begin{array}{l}\text { No. of } \\
\text { Workers }\end{array}$} & \multirow{3}{*}{$\begin{array}{l}\text { Segmental } \\
\text { Distribution } \\
\text { of Pain }\end{array}$} & \multicolumn{2}{|c|}{ No. with Pain } & \multicolumn{4}{|c|}{ No. off Work } \\
\hline & & & \multirow[t]{2}{*}{ Expected } & \multirow[t]{2}{*}{ Observed } & \multicolumn{2}{|l|}{ I Week + } & \multicolumn{2}{|c|}{3 Months + } \\
\hline & & & & & Expected & Observed & Expected & Observed \\
\hline $\begin{array}{l}\text { Heat } \\
\text { No heat } \\
\text { Mixed } \\
\text { Total }\end{array}$ & $\begin{array}{r}140 \\
61 \\
89 \\
290\end{array}$ & Dr2-L2 & $\begin{array}{l}40 \cdot 6 \\
19 \cdot 2 \\
27 \cdot 9 \\
87 \cdot 7\end{array}$ & $\begin{array}{l}41 \\
15 \\
28 \\
84\end{array}$ & $\begin{array}{l}22.5 \\
10.7 \\
15.8 \\
49.0\end{array}$ & $\begin{array}{r}29 \\
8 \\
14 \\
51\end{array}$ & $\begin{array}{r}10.6 \\
4.9 \\
7.5 \\
23.0\end{array}$ & $\begin{array}{c}9 \\
1 \\
2 \\
12 \star\end{array}$ \\
\hline $\begin{array}{l}\text { Heat } \\
\text { No heat } \\
\text { Mixed } \\
\text { Total }\end{array}$ & $\begin{array}{r}140 \\
61 \\
89 \\
290\end{array}$ & $L_{3-4}$ & $\begin{array}{r}15.4 \\
6.7 \\
11 \cdot 0 \\
33 \cdot 1\end{array}$ & $\begin{array}{l}7^{\star} \\
2 \\
3^{\star} \\
12\end{array}$ & $\begin{array}{r}10 \cdot 2 \\
4 \cdot 8 \\
7 \cdot 2 \\
22 \cdot 2\end{array}$ & $\begin{array}{l}2^{\star} \\
0 \\
2 \\
4\end{array}$ & $\begin{array}{r}5 \cdot 1 \\
2 \cdot 2 \\
3 \cdot 5 \\
10.8\end{array}$ & $\begin{array}{l}0^{\star} \\
0 \\
0 \\
0\end{array}$ \\
\hline $\begin{array}{l}\text { Heat } \\
\text { No heat } \\
\text { Mixed } \\
\text { Total }\end{array}$ & $\begin{array}{r}140 \\
61 \\
89 \\
290\end{array}$ & $\mathrm{~L}_{5}-\mathrm{S}_{2}$ & $\begin{array}{r}9 \cdot 7 \\
4.3 \\
7.6 \\
21 \cdot 6\end{array}$ & $\begin{array}{r}13 \\
4 \\
7 \\
24\end{array}$ & $\begin{array}{r}6.4 \\
2.8 \\
4.7 \\
13.9\end{array}$ & $\begin{array}{r}8 \\
0 \\
5 \\
13\end{array}$ & $\begin{array}{l}3 \cdot 5 \\
1 \cdot 3 \\
2 \cdot 5 \\
7 \cdot 3\end{array}$ & $\begin{array}{l}4 \\
0 \\
0 \\
4\end{array}$ \\
\hline
\end{tabular}

Heat = moulders, furnace hands, and welders.

No heat $=$ core and pattern makers and dressers.

Mixed $=$ other.

*Based on the total no. of workers who had radiographs of the lumbar spine.

N.B.-This table is based on the total workers examined clinically. Of the foundry workers clinically examined, $97 \%$ had

$\star \mathbf{P}<0.05>0.01$.

$+\mathbf{P}<0.001$. 
expected and less incapacity from pain in the D12L2, L3-4, and L5-S2 segmental distribution. In the case of the DI2-L2, L3-4 pain this difference was highly significant $(P<0.001)$. Loss of work from hip pain occurred in only one foundry worker. In relation to the amount of osteo-arthrosis, there was significantly less pain in the proximal interphalangeal $(P<0.001)$ and metacarpophalangeal $(P \simeq 0.05)$ joints in the foundry workers, and in the hips, first carpometacarpal, and distal interphalangeal joints it was also less, though not significantly so. Incapacity was less from pain at all sites radiographed except the wrists but was significantly less $(P \simeq 0.05)$ only in the proximal interphalangeal joints of the fingers. The miners did not have more than the expected frequency of symptoms in relation to the degree of radiological change.

Comparison of Different Types of Foundry Workers Since foundry workers are exposed to radiant heat more than other workers and since the pain threshold is known to be influenced by tissue temperature, it is important to know whether a reduction in symptoms is related to the degree of exposure to radiation. The foundry workers have therefore been divided into three groups $(a)$ the moulders, furnace hands, and welders who are exposed to considerable radiation, $(b)$ the core and pattern makers and dressers who work at some distance from the furnace and the pouring ladles, and $(c)$ a mixed group of general labourers whose exposure varies.

In Table IX the prevalence of back and leg pain

TABLE $\mathbf{X}$

Age Distribution and Grades of Disc Degeneration IN FOUNDRY WORKERS EXPOSED AND NOT EXPOSED TO Heat

Conditions of Work

\begin{tabular}{lrlll} 
& Heat & \multicolumn{3}{c}{ No Heat } \\
\cline { 2 - 5 } Age of those Y-rayed & & $(\%)$ & & $(\%)$ \\
$35-44$ & 67 & 48 & 28 & 46 \\
$45-54$ & 46 & 33 & 15 & 26 \\
$55-64$ & 26 & 19 & 18 & 29 \\
$65+$ & 1 & - & - & - \\
Total & 140 & - & 61 & - \\
Grades of disc & & & & \\
$\quad$ degeneration & & & & \\
Total & 140 & - & 61 & - \\
O & 10 & $7 \cdot 1$ & 15 & $24 \cdot 6$ \\
I & 15 & $10 \cdot 7$ & 11 & $18 \cdot 0$ \\
2 & 87 & $62 \cdot 1$ & 30 & $49 \cdot 2$ \\
3 & 23 & $16 \cdot 4$ & 5 & $8 \cdot 2$ \\
4 & 5 & $3 \cdot 6$ & 0 & - \\
$2-4$ & 115 & 82 & 35 & $57^{\star}$ \\
*P $<$ 0.001 & & & &
\end{tabular}

and resulting loss of work in those foundry workers exposed and not exposed to heat is shown and is compared with the expected prevalence assessed from the population of Leigh. The relative amounts of lumbar disc degeneration are not taken into account in this table. It will be observed that those workers who were exposed to heat showed about the same reduction in pain in the $\mathrm{L}_{3}-4$ distribution and in loss of work from this cause as those not exposed to heat, and the expected amount of pain in the other sites. The radiological changes of disc degeneration in the lumbar spine (Table X), however, were significantly greater at grades $\mathbf{2 - 4}$ in those working in heat $(\mathbf{P}<0.001)$ despite the fact that these workers were younger than those not so exposed and would be expected to have less disc degeneration. Thus it would be expected that the 'hot' workers would have much more pain.

\section{Discussion}

One of the most striking features in this survey was the low prevalence of rheumatic complaints in the foundry workers, particularly those complaints associated with prolonged incapacity.

This contrasts with data from the Ministry of Pensions and National Insurance and with the findings of Vernon (1921) already mentioned. The large number of claims on the Ministry of Pensions and National Insurance may well reflect a very considerable number at risk in the population but it indicates the need for surveys of other groups of metal workers. Vernon's data were derived from a comparison between certain groups of workers within the foundries, and no comparison was made with the general population.

The low complaint rate which we have encountered in the foundry workers cannot be attributed to poor memory for past painful episodes since there were fewer complaints present at the time of the survey. The deficit of prolonged incapacity was related mainly to knee, thigh, and tarsal pain. The low frequency of thigh and knee pain may be explained in part by the diminished frequency of osteo-arthrosis in the hips and knees in the foundry workers. It would, however, be expected that some thigh pain would result from the lumbar disc degeneration, which was more severe in the foundry workers. The third lumbar disc was more often affected than any other in the foundry workers, and the fourth was also commonly involved. Pain referred from these segments of the spine is felt in front of the thighs (Kellgren, 1940). Thus it would appear that some other factor is responsible. A possible explanation is that the pain threshold is raised as a result of the warm dry 


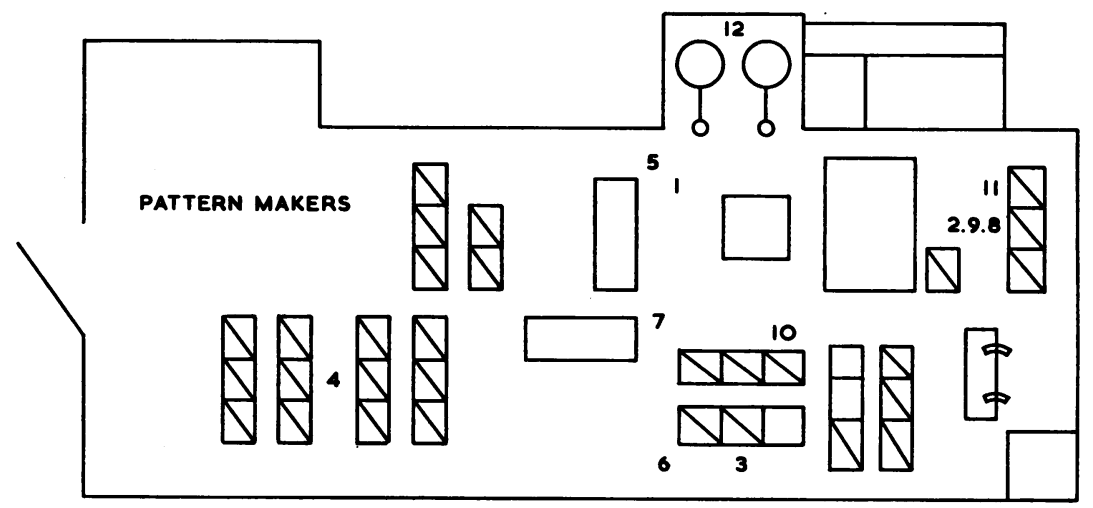

FIG. I. Thermal environment in the iron foundry. Location: ( 1 ) Ladle driver ro ft., $30^{\circ}$; (2) mould making; (3) mould pouring (a) $20 \mathrm{ft}$., back pot, (b) $10 \mathrm{ft}$., front pot, (c) ro ft., front pot; (4) full hot moulds; (5) tapping $20 \mathrm{ft}$., $60^{\circ}$; (6) mould pouring front I $5 \mathrm{ft}$.; (7) mould pouring front $20 \mathrm{ft} ., 30^{\circ}$; (8) mould pouring side $15 \mathrm{ft} ., 5^{\circ}$; (9) mould pouring front $12 \mathrm{ft}$.; (IO) mould pouring front $20^{\circ}, 30^{\circ}$; (II) after pouring; (I2) furnace.

atmosphere in the foundry, or from exposure to radiant heat from the molten metal. A relationship between pain threshold and tissue temperature is known to exist, and it has been found that the symptoms of both disc degeneration and osteoarthrosis are less frequent and disabling in miners working in warm dry seams than in those in cold wet seams (Kellgren, McGowan, and Hughes, I948; Lawrence, 1955).
Because of a possible association between exposure to radiant heat and the low prevalence of musculo-skeletal pain in these foundry workers, it was decided to study the conditions of work, particularly with reference to air temperature, radiant heat, and humidity.

Measurements were made in a typical small foundry during the pouring of molten iron $\left(\mathrm{I}, 500^{\circ} \mathrm{C}\right.$.). The intensity of radiation incident on

TABLE XI

Thermal Environment in I I Positions

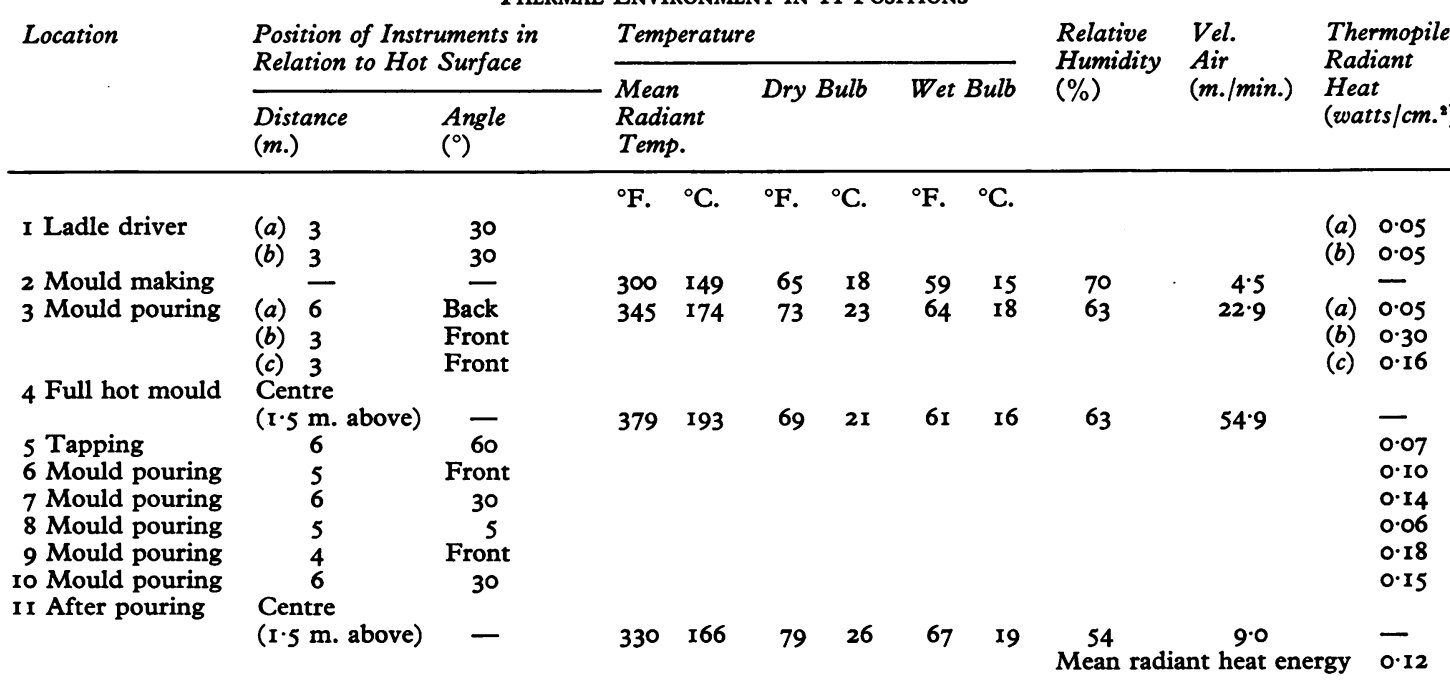

Technique of temperature and humidity measurements: ( 1 ) radiant heat, measured by radiation thermopile; (2) mean radiant temperature of surroundings, measured by globe thermometer; (3) air temperature and relative humidity, measured by dry and wet bulbs of whirling hygrometer. 
the workers was determined with a radiation thermopile. For comparative purposes, measurements of the intensity of radiation were made with the same instrument during radiant heat treatment in a physiotherapy department.

Thermal measurements, made in II places in the foundry (Fig. I), indicate the variation of working conditions (Table XI).

The mean radiant temperature of the surroundings measured by the globe thermometer in locations $2,3,4$, and II varied between $149^{\circ} \mathrm{C}$. and $193^{\circ} \mathrm{C}$. These readings were taken during the short period of intense radiant heat directed from the surface of the molten metal. During these operations there was a relatively small increase in air temperature and a reduction of humidity. The air movement throughout the foundry was low, varying between 4.5 and 54.9 metres/minute.

In the foundry, the radiant heat incident upon the body of the lightly clothed workman varied between 0.05 and 0.30 watt $/ \mathrm{cm} .{ }^{2}$, with a mean value of $0.12 \mathrm{watt} / \mathrm{cm}^{2}$, in eight locations. The exposure is intermittent and transitory, these conditions being experienced for approximately two hours on each of two days per week.

The results obtained in the foundry using the radiation thermopile have been compared with the radiant heat experienced during heat therapy (Table XII).

TABLE XII

Therapeutic Radiant Heat ('Radiant' and Infrared)

\begin{tabular}{lccc} 
Method & $\begin{array}{l}\text { Power of Heat } \\
\text { Source (W) }\end{array}$ & $\begin{array}{l}\text { Distance } \\
(\mathrm{cm} .)\end{array}$ & $\begin{array}{l}\text { Thermopile, } \\
\text { Radiant Heat } \\
\left.\text { (watt/cm. }{ }^{2}\right)\end{array}$ \\
\hline Radiant heat & 1000 & 76 & 0.16 \\
Radiant heat & 1000 & 58 & 0.37 \\
Infrared & 600 & 76 & 0.22 \\
Infrared & 600 & 58 & 0.30 \\
Infrared & 600 & 58 & 0.31
\end{tabular}

In comparison, a patient undergoing 'radiant heat' therapy can be exposed to between 0.16 and 0.37 watt $/ \mathrm{cm}^{2}{ }^{2}$, whereas the exposure during 'infrared' therapy is between 0.22 and 0.31 watt $/ \mathrm{cm} .{ }^{2}$. In normal circumstances heat therapy would normally be given for three periods of 30 minutes each week for two months. Relief of pain occurs in some $80 \%$ of rheumatic sufferers during such therapeutic exposures and has a mean duration of yo hours following exposure to radiant heat (Lawrence and Sladden, 1955). In some patients relief may last up to 48 hours, and it seems reasonable to suppose that in those with mild rheumatic disorders the complaint rate and capacity for work might be influenced by the amount of radiation received in the foundry.

The increased prevalence of disc degeneration in the foundry workers is not unexpected. An association between heavy lifting and disc degeneration has already been demonstrated in other occupations (Lawrence, 1955). Although mechanical lifting has now replaced much of the heavy manual work associated with foundries, the earlier years must inevitably have produced permanent changes in the discs. The greater prevalence of disc degeneration in those foundry workers directly exposed to hot conditions may be due to the heavier nature of their work, but a higher pain threshold might also play a part. The relatively high prevalence of symptoms due to lumbar disc prolapse may be explained by the fact that pain in these cases is due to root pressure which may not be influenced by tissue temperature to the same extent as referred pain. Moreover, the initial symptoms of disc degeneration are more likely to go unheeded by a worker in a warm environment until rupture of the annulus ensues.

The lower prevalence of osteo-arthrosis in the weight-bearing joints, such as the hips, knees, and lumbar spine, suggests an influence of body habitus. Obesity has been shown to be associated with a greater prevalence of osteo-arthrosis in these joints and was in fact less frequent in the foundry workers. Only $15 \%$ of the foundry workers were graded as having even minimal obesity compared with an expected rate of $31 \%$ as judged from the Leigh random sample in this age distribution. An unexplained association between obesity and osteoarthrosis of the distal interphalangeal joints was noted in the Leigh random sample and is reflected in a low frequency of osteo-arthrosis in these joints in foundry workers (Kellgren and Lawrence, 1958). The absence of obesity in foundry workers is presumably associated with the strenuous nature of the work and the relatively warm working conditions.

We wish to express our thanks to members of the North Western Ironfounders Employers' Association and the National Light Castings Ironfounders' Federation, Glasgow and to officials and members of the Amalgamated Union of Foundry Workers and the Transport and General Workers Union for their willing co-operation in this survey.

We are indebted to Professor R. E. Lane and Dr. W. R. Lee for much advice, helpful comments, and criticism.

\section{REFERENCES}

Atlas of Standard Radiographs of Arthritis (1963). Blackwell, Oxford.

Bier, J., Bremner, J. M., and Lawrence, J. S. (1965). In press. Bremner, J. M. (196I). Ann. rheum. Dis., 20, 149.

Kellgren, J. H. (1940). Clin. Sci., 4, 303.

$\longrightarrow$ McGowan, A. J., and Hughes, E. S. R. (1948). Ibid., 7, 13. 
Kellgren, J. H., and Lawrence, J. S. (1952). Brit. F. industr. Med., 9, 197.

and - (1958). Ann. rheum. Dis., 17, 388.

Lawrence, J. S. (1955). Brit. F. industr. Med., 12, 249. (196I). Ann. rheum. Dis., 20, II.

(1963). Brit. F. clin. Pract., 17, 699.

and Bennett, P. H. (1960). Ann. rheum. Dis., 19, 20. de Graff, R., and Laine, V. A. I. (1963). In The Epidemiology of Chronic Rheumatism. Ed. by M. R. Jeffrey and J. Ball under the direction of J. H. Kellgren, Vol. 2, p. 98. Blackwell, Oxford. and Sladden, R. J. (1955). Ann. phys. Med., 2, 282. Vernon, H. M. (1921). f. industr. Hyg., 3, 93. 